\title{
Factors and Effect of Poor Background on the Students Academic Performance in Physics at Senior Secondary School in Birnin Kebbi Metropolis
}

\author{
Kamba A.H*, Oladayo A.A, Fakai A.A
}

Kebbi State University of Science and Technology, Aliero, Department of Science Education, Kebbi State, Nigeria

DOI: $10.36348 /$ sjet.2020.v05i03.004 $\quad$ | Received: 19.03 .2020 | Accepted: 26.03 .2020 | Published: 30.03 .2020

*Corresponding author: Kamba A. H

\section{Abstract}

The study investigated the effect of poor academic background on students' performance in physics in Birnin Kebbi Metropolis. The study adopted descriptive survey design to collect data on effect of poor background on students' performance in physics in Birnin Kebbi Metropolis. From the population of 5,285 students' and 34 teachers', using stratified sampling; six (6) schools were selected in three strata that is mixed schools, Boys schools and Girls schools. Further, in each sampled school only 30 (ss2) students' were involved in the study and 2 physics teachers'. Data were collected using questionnaire for the physics teachers and (ss2) students' in the sampled schools. The findings were summarized and reported using percentage and frequency distribution tables. The study found and concluded that family background, teachers' attitude towards work, methods of teaching and gender affect students' performance in physics in senior secondary school in Birnin Kebbi Metropolis. Finally, the study recommended that policy makers/ministry of Education should ensure proffer curriculum implementation by physics teachers and increase enrolment in physics.

Keywords: Factors and Effect, Poor background, Student performance in Physics.

Copyright @ 2020: This is an open-access article distributed under the terms of the Creative Commons Attribution license which permits unrestricted use, distribution, and reproduction in any medium for non-commercial use (NonCommercial, or CC-BY-NC) provided the original author and source are credited.

\section{INTRODUCTION}

\section{Background to the Study}

Physics as a course of study is very stimulating and rewarding subject, its study prepares the students to obtain the ability of thinking critically and how to solve problems. Physics is a natural science that involves the study of matter and its motion through space and time, along with related concepts such as energy and force. In other words, it is the phenomenon or system pertaining to the physical aspects. Physics is an important science subject that makes enormous academic demands on students in its learning. The learning of physics is difficult at best and almost impossible at worst. But because of its great importance to science and technology, there is understandably huge interest in students' achievement in physics. Thus, the background of students' performance in physics has generated a huge deal of discussion for a long time. Most subjects (Physics included) offered at senior secondary school level have some factors which have problems that affect the assimilation of students. The poor academic performance of students in physics at senior secondary school level has been a subject of concern to many people including parents, administrators, educators, psychologists and counselors. Poor academic performance according to Aremu [1], "is a performance that is adjudged by the examine/testee and some other significant as falling below an expected standard". Also, Aremu, [2] "stresses that academic failure is not only frustrating to the pupils and the parents, its effects are equally grave on the society in terms of dearth of manpower in all spheres of the economy and politics". Various factors have been identified in several research studies to be responsible for continuous decaying of our educational system. Such factors include; Family background, lack of interest of the student, attitude of teachers towards work, methods of teaching used by the teacher, gender, environmental factors, poor primary school background in science, teachers qualification and inadequate laboratory facilities. Orhungur [3], "asserted that the cultural background of the family is determined to a large extent by its socio-economic background. The setting and socializing influence of the family mold the personality of the child". Morankiyo [4], "believes that the falling level of academic achievement is attributed to teachers non-use of verbal reinforcement strategy". Others found out that the attitude of some teachers to their job is reflected in their 
Kamba A.H et al., Saudi J Eng Technol, March. 2020; 5(3): 114-119

poor attendance to lessons, lateness to school and unsavory comments about students' performance. The national policy on Education (NPE) [5], stipulated that primary Education is an instrument for national development that fosters the worth and development of the individual for further Education, general development of the society and equality of Educational opportunities to all Nigerian children irrespective of real or marginal disabilities. However, different people at different time have passed the blame of poor performance to students because of their low retention, parental factors, association with wrong peers, low achievement and the likes [1, 6, 2]. Saage [7], identified specific variables such as poor primary school background in science, lack of incentives for test, lack of interest on the parts of students, students not interested in hard work, incompetent teachers in primary schools, large classes, and fear of the subject psychologically. Despite all the possible efforts put forward by various government and voluntary agencies to curb the trends, the country is yet to witness the rise it wishes to see in the Educational system. Therefore, the researcher's interest and motivation in this topic is the fact that some students are particularly good in their work, while some are extremely bad. When such differences in scores are traced, it is more often discovered that the background is the major contributory factor. Therefore, it is more important that such levels of contributions and effects that background have on children be examined so that useful suggestions to parents, teachers, Educational planners and government could be made.

\section{Statement of the Problem}

In recent years, a great awareness has developed among parents, teachers, Educators, government officials, researchers and Educational planners over those factors that affect students' performance in physics in Nigeria. It has been quite clear that student's performance in physics as well as participation (especially in Birnin kebbi Metropolis) is poor and require immediate attention. All over the country, there is a consensus of opinion about the falling standard of Education in Nigeria [8]. Improvement in students' performance has become the researchers concern. It is therefore based on this issue, this study was designed to determine the factors and effect of poor background on the students' academic performance in physics at senior secondary school level in Birnin kebbi Metropolis.

\section{Objectives of the Study}

The main of this study is to examine the factors and effect of poor background on the students' academic performance in physics at senior secondary school level in Birnin kebbi Metropolis with following specific objectives.

1. To determine the effect of family background on students' performance in physics.
2. To find out the effect of teachers' attitude towards work on students' performance in physics

3. To ascertain the teaching method use by the physics teachers in teaching physics

4. Determine the effect of gender on students' performance in physics

\section{Research Questions}

For the purpose of this research work, the following research questions have been formulated;

1. Do family background have any effect on students' performance in physics?

2. What is the effect of teachers' attitude towards work on students' performance in physics?

3. Which type of teaching method do physics teachers use in teaching physics at senior secondary school level?

4. What is the effect of gender on students' performance in physics?

\section{Research Hypothesis}

The following hypothesis would be tested to guide this study;

Ho1: There is no significant relationship between family background and students' performance in physics

Ho2: There is no significant relationship between teachers' attitude towards work and students' performance in physics

Ho3: There is no significant relationship between methods of teaching used by teachers and students performance in physics

Ho4: There is no significant relationship between gender and students' performance in physics.

\section{Significance of the Study}

The study will be of significance to a number of beneficiaries in the sense that it will provide information on effect of family background on students' performance in physics. It will also give information on how students' interest and attitude of teachers towards work affect students' performance in physics. However, it will provide information on effect of environmental factors and methods of teaching employed by teachers on students' performance in physics. Furthermore, it will give information that would guide curriculum planners in planning the curriculum without rigidity to suit diverse cultural environment. Also, it will provide information which is likely to help Kebbi State in particular and Nigeria in genera in terms of knowing the possible solutions on how to improve students' performance in physics.

\section{Scope and Limitations}

This study is limited to schools that offer physics subject in Birnin Kebbi Metropolis. 
Kamba A.H et al., Saudi J Eng Technol, March. 2020; 5(3): 114-119

The List of Schools Are

1. Salamatu Husaini Government Day Secondary School Birnin Kebbi.

2. Nagari Science Collage Birnin-Kebbi.

3. Government Girls Collage (UNITY) Birnin Kebbi

4. Polytechnic Staff Academy Birnin Kebbi.

5. G.D.S.S Junju Birnin Kebbi

6. Abdullahi Fodio Government Day Secondary School Birnin Kebbi.

\section{METHODOLOGY \\ Research Design}

Descriptive survey design was adopted. This enables the researchers to obtain and asses' opinions, attitudes and practices of physics teachers and senior secondary schools (ss2) students'. According to Polit and Hungler [9], a survey obtains information on a sample of people by means of self-report, that is, the people respond to series of questions posed by the investigator. The design helped to describe the effect of poor background on students' performance in physics at senior secondary school level (public schools) in Birnin Kebbi Metropolis. According to Ogula [10], descriptive research design attempts to accurately describe a given situation. This design was used to collect information, record the information collected, analyze and report conditions that existed.

\section{Population of the Study}

The population of the study is senior secondary schools offering physics subject and their physics teacher's in Birnin Kebbi metropolis.

\section{Sample Size and Sampling Technique}

The sampling size was limited to six (6) senior secondary schools (ss2) students' who have completed the recommended physics scheme of work for two years. The six schools were selected by the means of simple random sampling technique. In each of these six schools, thirty (30) students' were randomly selected. This brings a total of one hundred and eighty (180) and two (2) physics teachers from each school were selected. According to Heiman [11], stratified random sampling is a sampling technique that involves the identification of important sub-groups in a particular population. In this case the sub-groups were mixed schools, boys' schools and girls' schools. To allocate the sample size in the stratum, proportional sampling method was used. At the school level the study used purposive sampling. Therefore the study only involves senior secondary schools (ss2) who have already made their subject choice. Finally at the class level "randomly drawn" was used in sampling. In mixed schools proportional sampling method was used to ensure boys and girls were equally represented. The Table- 1 below shows the representation of strata in three categories of schools.
Table-1: Representation of Strata in the Categories of Schools

\begin{tabular}{|l|l|l|}
\hline Strata/nature of school & Population & Sample \\
\hline Mixed schools & 521 & 60 \\
\hline Boys' schools & 572 & 60 \\
\hline Girls'schools & 334 & 60 \\
\hline Total & $\mathbf{1 4 2 7}$ & $\mathbf{1 8 0}$ \\
\hline \multicolumn{2}{|l}{ Source: (Field work 2018) } \\
\hline
\end{tabular}

\section{Instrument for Data Collection}

The study employed questionnaires for teachers and students'. The questionnaires include both open and closed ended items. According to Orodho [12], the close ended items were used because they are easy to fill, relatively objective and easy to tabulate. The open ended items were used to allow teachers and students' to express themselves freely without restriction. The questionnaires consist of two sections, where section one contained items that generated demographic data while section two contained items on effect of poor background on students' performance in physics.

\section{Validity of the Instrument}

According to Mugenda and Mugenda [13], validity is the accuracy and meaningfulness of inference, which are based on researcher's result. Validity means the accuracy with which a test measures what it is or what it intends or supposed to measure. Thus, the first draft of the questionnaire was given to expert in the Department of Science Education, Faculty of Education and Extension Services, Kebbi State University of Science and Technology Aliero to validate, and make necessary corrections to avoid ambiguity.

\section{Pilot Study}

The pilot study was carried out in three randomly chosen schools (one from each stratum) in birnin kebbi metropolis.

\section{Reliability of the Instrument}

According to Mugenda and Mugenda 14], reliability is a measure of the degree to which an instrument yields consistent results or data after reported trials. The split half technique was employed to test the reliability of the instrument. In this approach, an instrument is designed in such a way that there are two parts. Therefore, the questionnaires are divided into two sections using spearman rank order correlation coefficient to determine reliability of the instruments. The coefficient of 0.70 was obtained for the students' questionnaires and 0.71 for the teachers questionnaires. All the instruments were reliable. According to Rama [15], an instrument with 0 as coefficient is full of error, while with 1 shows the absence of error. Any instrument with 0.5 and above as coefficient is reliable. 


\section{Procedure for Data Collection}

Each selected physics teacher was given a questionnaire. The respondents were given adequate explanation before filling the forms. In the administration of students' questionnaires, the assistance of physics teachers was sought. The teachers assisted in distributing the questionnaires to the students'. After two (2) weeks the questionnaires were collected from the respondents.

\section{Procedure for Data Analysis}

After administration of the instrument to the respondents, the data was examined for completeness so that it can be coded appropriately. Descriptive statistics such as percentages, means and frequency will be used to present data. The findings would be reported in summary form using frequency distribution tables and pie charts.

\section{DATA ANALYSIS AND PRESENTATION INTRODUCTION}

This chapter presents data analysis, presentation and discussion of the study the data were collected from 192respondents (180 students and 12teachers) from six senior secondary schools, (ss2) Student in Birnin Kebbi Metropolis. This gave a response rate of $100 \%$. The research focuses on various factors that affect student performance in physics at senior secondary school in Birnin Kebbi Metropolis. The result were presented and discussed in accordance with the research objectives and questions. Simple percentages were employed as statistically tool in the data analysis.

\section{Analysis of the Questionnaire}

Table-2: Effect of Family Background on Students' Performance in Physics

\begin{tabular}{|l|l|l|}
\hline Option & Frequency & Percentage \\
\hline Yes & 9 & $75 \%$ \\
\hline No & 3 & $25 \%$ \\
\hline Total & 12 & $100 \%$ \\
\hline \multicolumn{3}{|c|}{ Source: (field work 2018) }
\end{tabular}

Table-2, Shows that $75 \%$ (9) of teachers believed that family background affect students' performance in physics while $25 \%$ (3) of teachers didn't believe that family background affect student performance in physic. Therefore, study show that majority of the teachers $(75 \%)$ believed that family background affect students' performance in physics and only $25 \%$ of the teachers response that family background does not affect student performance in physics.

Table-3: Students' Interest in Physics

\begin{tabular}{|l|l|l|}
\hline Option & Frequency & Percentage \\
\hline Yes & 101 & $56.1 \%$ \\
\hline No & 79 & $43.9 \%$ \\
\hline Total & $\mathbf{1 8 0}$ & $\mathbf{1 0 0 \%}$ \\
\hline \multicolumn{3}{|c|}{ Source (field work 2018) }
\end{tabular}

Table-3, Shows that $56.1 \%$ (101) of the student have interest in studying physics while $43.9 \%$ (79) don't have interest in studying physics. Therefore, this shows that majority of the students have interest in studying physics only few of the students have no interest in studying physics.

Table-4: Teachers Attitude towards Work as Rated by Students'

\begin{tabular}{|l|l|l|}
\hline Option & Frequency & Percentage \\
\hline Excellent & 42 & $23.3 \%$ \\
\hline Good & 56 & $33.9 \%$ \\
\hline Satisfactory & 61 & $33.9 \%$ \\
\hline Poor & 21 & $11.7 \%$ \\
\hline Total & $\mathbf{1 8 0}$ & $\mathbf{1 0 0 \%}$ \\
\hline \multicolumn{3}{|c|}{ Source: (field work 2018) }
\end{tabular}

Table-4, Shows that only $23.3 \%$ (42) of students' rated teachers are having excellent attitude towards their work,31.1\% (56) had a good attitude, while $33.9 \%$ (61) had a satisfactory attitude and $11.7 \%$ (21) of the student rated the teachers were having poor attitude towards their work.

\section{Table-5: How Many Teachers are Trained to Teach Physics?

\begin{tabular}{|l|l|l|}
\hline Option & Frequency & Percentage \\
\hline Trained & 10 & $83.3 \%$ \\
\hline Not Trained & 2 & $16.7 \%$ \\
\hline Total & $\mathbf{1 2}$ & $\mathbf{1 0 0 \%}$ \\
\hline \multicolumn{2}{|c|}{ Source (field work 2018) }
\end{tabular}

Table-5, Shows that $83.3 \%$ (10) percent of the teachers were trained to teach physics while only $16.7 \%$ (2) are not properly trained to teach physics.

Table-6: How Many Teachers Enjoy Teaching Physics?

\begin{tabular}{|l|l|l|}
\hline Option & Frequency & Percentage \\
\hline Those Enjoy & 101 & $56.1 \%$ \\
\hline Not Enjoy & 79 & $43.9 \%$ \\
\hline Total & $\mathbf{1 8 0}$ & $\mathbf{1 0 0 \%}$ \\
\hline
\end{tabular}

Source (field work 2018)

Table-6, the result Shows that $56.1 \%$ (101) of the teachers enjoy teaching physics while $43.9 \%$ (79) did not enjoy teaching physics.

Table-7: Methods of Teaching Employed

\begin{tabular}{|l|l|l|}
\hline Option & Frequency & Percentage \\
\hline Lecture method & 3 & $25 \%$ \\
\hline $\begin{array}{l}\text { Demonstration } \\
\text { method }\end{array}$ & 3 & $25 \%$ \\
\hline Discussion method & 4 & $33.3 \%$ \\
\hline Discovery method & 2 & $16.7 \%$ \\
\hline Total & $\mathbf{1 2}$ & $\mathbf{1 0 0 \%}$ \\
\hline
\end{tabular}

Source (field work 2018)

Table-7 Above indicates that $25 \%$ (3) of the teachers used lecture method in teaching physics, another $25 \%$ (3) used demonstration method while $33.3 \%$ (4) used discussion method and $16.67 \%$ (2) used discovery method in teaching physics. Therefore, the 
Kamba A.H et al., Saudi J Eng Technol, March. 2020; 5(3): 114-119

finding shows that discussion method (33.33\%) used more often by teachers in teaching physics than lecture method (25\%), demonstration method (25\%) and discovery method $(16.67 \%)$.

Table-8: Lesson Presentation of the Physics Teacher

\begin{tabular}{|l|l|l|}
\hline Option & Frequency & Percentage \\
\hline Yes & 93 & $51.7 \%$ \\
\hline No & 87 & $48.3 \%$ \\
\hline Total & $\mathbf{1 8 0}$ & $\mathbf{1 0 0 \%}$ \\
\hline \multicolumn{2}{|c|}{ Source (field work 2018) }
\end{tabular}

Table-8 Shows that $51.7 \%$ (93) of the students enjoy presentation of the lesson by their physics teachers while $48.3 \%$ (87) of the students' did not enjoy the lesson presentation by their physics teachers. Therefore, the finding shows that the majority of the students' enjoy the lesson presentation of their physics teachers.

Table-9: Kind of Language Physics Teacher Use
\begin{tabular}{|l|l|l|}
\hline Option & Frequency & Percentage \\
\hline Simple language & 97 & $53.9 \%$ \\
\hline Difficult terms & 80 & $44.4 \%$ \\
\hline Proverb & 3 & $1.7 \%$ \\
\hline Total & $\mathbf{1 8 0}$ & $\mathbf{1 0 0 \%}$ \\
\hline
\end{tabular}

Table-9 Above shows that 53.9\% (97) of students responded that their physics teachers use simple language during content delivery, $44.4 \%$ (80) responded that their physics teacher use difficult terms and $1.7 \%$ (3) responded that their physics teachers use proverbs during content delivery.

Table-10: Laboratory Equipment

\begin{tabular}{|l|l|l|}
\hline Option & Frequency & Percentage \\
\hline Yes & 5 & $25 \%$ \\
\hline No & 9 & $75 \%$ \\
\hline Total & $\mathbf{1 2}$ & $\mathbf{1 0 0 \%}$ \\
\hline \multicolumn{3}{|c|}{ Source (field work 2018) }
\end{tabular}

Table-10 The result study shows that $25 \%$ (5) of teachers responded that laboratories are well equipped with laboratory facilities while $75 \%$ (9) of teachers responded that laboratories were not well equipped with facilities. Therefore, most of the school's laboratories have inadequate practical facilities which may cause so much failure for achieving physics objectives, since most of the physics topic deal with practical's.

Table-11: Teaching of Practical Lesson in the Laboratory

\begin{tabular}{|l|l|l|}
\hline Option & Frequency & Percentage \\
\hline Yes & 8 & $66.7 \%$ \\
\hline No & 4 & $33.3 \%$ \\
\hline Total & $\mathbf{1 2}$ & $\mathbf{1 0 0 \%}$ \\
\hline \multicolumn{2}{|c|}{ Source (field work 2018) }
\end{tabular}

Table-11 Shows that $66.7 \%$ (8) of teachers teach practical lessons in the laboratories while $33.3 \%$ (4) do not teach practical lesson in the laboratory.
Table-12: Are Practical Lesson Taught in the Laboratory?

\begin{tabular}{|l|l|l|}
\hline Option & Frequency & Percentage \\
\hline Yes & 72 & $40 \%$ \\
\hline No & 108 & $60 \%$ \\
\hline Total & $\mathbf{1 8 0}$ & $\mathbf{1 0 0 \%}$ \\
\hline \multicolumn{2}{|c|}{ Source (field work 2018) }
\end{tabular}

Table-12 Shows that $40 \%$ (72) of the student respond that practical lesson are taught in the laboratory and $60 \%$ (108) of student believed that practical lessons were not taught in the laboratory.

Table-13: Role of Gender

\begin{tabular}{|l|l|l|}
\hline Option & Frequency & Percentage \\
\hline Yes & 7 & $58.33 \%$ \\
\hline No & 5 & $41.67 \%$ \\
\hline Total & $\mathbf{1 2}$ & $\mathbf{1 0 0 \%}$ \\
\hline \multicolumn{2}{|c|}{ Source (field work 2018) }
\end{tabular}

Table-13 Shows that $58.33 \%$ (7) of teachers believed that gender plays a role in the performance of student in physics while $41.67 \%$ of teachers did not agree that gender play a role in student performance in physics. Thus, the study found that the majority of the teachers believed that gender plays a significant role towards understanding of physics.

Table-14: How Do You Feel During Physics Lecture?

\begin{tabular}{|l|l|l|}
\hline Option & Frequency & Percentage \\
\hline Motivated to read more & 55 & $30.6 \%$ \\
\hline Lack of motivation & 47 & $26.1 \%$ \\
\hline Tired and sleepy & 78 & 43.3 \\
\hline Total & $\mathbf{1 8 0}$ & $\mathbf{1 0 0 \%}$ \\
\hline
\end{tabular}

Source (field work 2018)

Table-14 Show that $30.6 \%$ (55) of students feel motivated when studying physics, $26.1 \%$ (47) of students' lack of motivation and $43.3 \%$ (78) of students feel tired and sleepy when studying physics. Therefore, this show that majority of the students $(43.3 \%)$ feel tired and sleepy when studying physics.

\section{SUMMARY}

The purpose of this study is to determine the effect of poor background on students' performance in physics at senior secondary school in Birnin Kebbi Metropolis. Four factors were considered family background, students' interest, teachers' attitude towards wok, Different methods of teaching used by teachers, gender and environmental factors which forms the research questions. Based on the research findings $75 \%$ of the teachers believed that family background affect students' performance in physics while $25 \%$ of teachers didn't believed that family background affect students' performance in physics. $56.1 \%$ of students' have interest in studying physics while $43.9 \%$ are not interested. $23.3 \%$ of students rated the attitude of their teachers towards work as excellent, $31.3 \%$ as good, 
$33.9 \%$ as satisfactory and $11.7 \%$ as poor. Also, teachers in Birnin kebbi metropolis employed different methods of teaching; $25 \%$ of teachers employed lecture method another $25 \%$ use demonstration method, while $33.3 \%$ employed discussion method and $16.7 \%$ employed discovery method. $53 \%$ of teachers believed that gender plays a role in students' performance in physics while $41.7 \%$ did not agreed. $25 \%$ of teachers respond that their school laboratories are well equipped with facilities but $75 \%$ respond that their school laboratories are not well equipped with facilities.

\section{CONCLUSION}

The conclusion drown from this study examined the factors and effect of poor background on the student academic performance in physics at senior secondary school in birn in Kebbi metropolis.

The result of the study clearly show that gender has effect on the performance of students toward physics subject, developing Students' attitude positively increases and motivates students' interest in the study of physics which in turn brings positive development to both the nation and the individual. Students' interest toward studying physics subject should be developed in both boys and girls. This is because girls showed low interest or negative attitude toward physics subject; there is need for both parent and teachers to encouragement the student to have more interest toward physics subject. The encouragement should be continuously until these factors militating against students' performance in Physics are addressed.

\section{RECOMMENDATION}

1. Parents/Guardian should encourage and motivate their children by providing necessary materials for science Education.

2. Physics teachers should avoid missing classes and head-teachers should take their responsibility of curriculum instruction and supervision, and ensure lessons are not missed.

3. Physics teachers should employ appropriate method of teaching physics.

4. Policy makers/ministry of Education should ensure proper curriculum implementation by physics teachers and increased enrolment in physics.

\section{REFERENCES}

1. Aremu, A. O., \& Sokan, B. O. (2003). A multicausal evaluation of academic performance of Nigerian learners: Issues and implications for national development. Department of Guidance and counseling, University of Ibadan.

2. Aremu, A. O. (2000). Academic performance 5 factor inventory Stirling-Horden publishers,
Ibadan A.S. Hornby, (2005). Oxford advanced learner's Dictionary $\left(7^{\text {th }}\right.$ edition) of current English.

3. Orhungur, M. M. (1990). Educational trinity, home, child, school. Jos: Fab Arich Nig. Ltd.

4. Morakinyo, A. (2003). Relative efficacy of systematic desensitization, self statement monitoring and flooding on students test anxiety. Unpublished PhD. Thesis. University of Ibadan.

5. Federal Republic of Nigeria. (2004). National policy on education.

6. Aremu, A. O., Oluwole, D. A., \& Fayombo, G. A. (2001). Secondary school students academic performance; an evaluation of the predicting effects of five variables. Ilorin Journal of Education, 1(4), 69-78.

7. Saage, O. (2009). Causes of mass failure in science Examination among students', a commissioned paper presented at Government secondary school. Karu Abuja Science Day $1^{\text {st }}$ March.

8. Adebule, S. O. (2004). Gender differences on a locally standardized anxiety rating scale in mathematics for Nigerian secondary schools. Nigerian Journal of counselling and applied psychology, 1(2), 22-29.

9. Polit, D., \& Hungler, B. (1993). Essential of nursing research $3^{\text {rd }}$ Edition. Philadephia, pa: lippincott.

10. Ogula, P. A. (1999). Research methods the catholic University of Eastern Africa, Nairobi.

11. Heiman, T. (2002). Parents of children with disabilities: Resilience, coping, and future expectations. Journal of developmental and physical disabilities, 14(2), 159-171.

12. Orodho, J. A. $2^{\text {nd }}$ (2009). Elements of Education and social science research methods Maseno: Kanezja publisher.

13. Mugenda, O. M., Hira, T. K., \& Fanslow, A. M. (1990). Assessing the causal relationship among communication, money management practices, satisfaction with financial status, and satisfaction with quality of life. Lifestyles, 11(4), 343-360.

14. Mugenda, O. M., \& Mugenda, A. G. (1999). Research methods qualitative and approaches: Nairobi: Acts press.

15. Lyles, C. M., Kay, L. S., Crepaz, N., Herbst, J. H., Passin, W. F., Kim, A. S., ... \& Mullins, M. M. (2007). Best-evidence interventions: findings from a systematic review of HIV behavioral interventions for US populations at high risk, 2000-2004. American journal of public health, 97(1), 133-143. 